\title{
Political Communication Chairman Of West Java Parliament : Political Identity Of Sundanese Woman As Political Symbols
}

\author{
Adiyana Slamet \\ Communication Science Departement, \\ Faculty of Social and Political Science \\ Universitas Komputer Indonesia \\ Bandung, Indonesia \\ Deby Sri Aprilliani \\ Communication Science Departement, \\ Faculty of Social and Political Science, \\ Universitas Komputer Indonesia \\ Bandung, Indonesia
}

\author{
Dadang Rahmat Hidayat \\ Faculty of Communication Science, \\ Universitas Padjadjaran \\ Bandung, Indonesia
}

\author{
Karim Suryadi \\ Faculty of Education Social Science, \\ Universitas Pendidikan Indonesia \\ Bandung, Indonesia
}

\begin{abstract}
This research intends to know the political communication method of the Chairman of Wes Java Parliament Ineu Purwadewi in showing up the political identity of Sundanese woman as political symbols. This research used qualitative approach with design of case studies. The used of political symbols in political communication are consisted of three instruments that is political communication with usage of political identity raises the symbol of clothing, symbol of color, symbol of language. The result of the research did is at perspective of socio-cultural. how language plays a very important role that breeds culture in life or the reality in society. Sundanese asset value is an identity that used in political communication space and then incarnate become political identity that attached on people is ethnophilosophical building in West Java. Based on the result of the research that has been described about the political communication Chairman of West Java Province Parliament for the period of 2014 - 20192019 in showing up political identity of Sundanese woman, can be concluded that; Politcal identity of Sundanese woman raises the political symbol which is "pseudo of the political symbols of a Sundanese woman" that is pretense or fake political symbol. The symbol that is "pseudo of the political symbols of a Sundanese woman" will have to result on "quasi of the political symbols" that is a pseudo-political symbol, in political communication orientation is short-term and pragmatic. The exchange of the political identity in political communication raises the political symbol of Sundanese woman who attached is "pseudo of political identity." As a Sundanese woman, political communication Chairman
\end{abstract}

of West Java Province Parliament for the period of 2014 - 2019 should have been raising the Sundanese political identity and implemented in political communication space and become a life foundation.

Keywords- Political Communication, Sundanese Woman, Political Symbol, Political Identity, West Java.

\section{I.INTRODUCTION}

Political communication is people's messaging activity that execute political activities, in the form of influencing or stimulating the others to do political activity, either at the level of superstructure and infrastructure relationship. The message occur to follow the changes and development of desired information in society. The actor or political communicator can also be called political participant can understand that the content, the purpose, and the desire of the delivered political messages are to affect and create the public opinion [1]. Political communication includes all form of symbol exchange or message which reaches a certain level is affected or affect the functioning of the political system. In local political dynamics, political identity become central in West Java space. Political identity in people's construction can be positive or negative. Positive mean become encouragement to admit and acomodate the differences, even to the extent of recognizing the privileges predicate of an area towards other area based on historically and logically reason. Negative when there is injustise between one group and another, for example the majority domination towards minority. The dominance can be born from the group struggle, and it more dangerous if it legitimized by the country. The state is overcoming every groups with its necessity and its interest and arrange and make the regulation to create a harmony [2]. The political 
communication that Ineu Purwadewi Sundari, the Chairman of West Java Province Parliament for the period of $2014-2019$ is by showing up the Sundanese women symbols is in line with the prespective of political symbolism, or the prespective of symbolic interaction in political context. This thing is based on assumptions that "political talk is symbolic activity", Accordingly, political transaction, symbolism in politic become important in political communication [3].

The researcher started with review some of the previous research. This is intended to strengthen literature review in the term of existing research, although there are equation or differences is a natural thing and can be synergized to complete each other. As well as the dissertation research of Karim Suryadi, 2006 titled Kiai Political Communication in Forming Party Identity [5]. The differences with this research are different in research's object, political communcication legislative candidate and West Java governor candidates, so that, the political communication process will be different. [6].The difference with this research are different in research's object, how would the candidate reassuring The Political Party to get a vehicle through a letter of recomendation in Governer election so that its more dynamic in its political communication process.

. The differences with this research are the subject and object, if this research study and analyze the female representation in Riau Province Legislative for the period of $2004-2009$. While the research that researcher did is about political communication chairman of West Java Province Parliament in showing up Sundanese woman political identity as political symbols [7]. The research use qualitative method with case study as its research's design. The differences with this research are the object, subject, and the location is different. POlitical communication Chairman of West Java Province Parliament in showing up Political identity of Sundanese Woman as political symbols [8].

The dissertation research of Perception of Women in Political Leadership in Nigeria have differences, that is the object, subject, and the reserch's design is different. If the research that Annette Anigwe did more emphasis on women political partisipation in Nigeria, the research that researcher did that is about political communication Chairman of West Java Province Parliament in showing up Political identity of Sundanese Woman as political symbols with case study as its research's design [9]. Then the thesis research of Women and Political Participation, A minor Field Study on Hindrances for Women's Political Participation in Georgia have differences, that is the case study research's design with feminism theory[10]. Then, Mediterranean Jurnal of Social Science focus on how to win voters' hearts in DKI Jakarta Givernor election and the object and subjet are different. The previous researches become important because will bring up the position of the researcher in seeing the political communication reality, that in research interpretation that researcher will do there must be differences which is fundamental as the basis of the researcher to showing up research originality that researcher will do [11].

Case study of political communication chairman of West Java Province Parliament for the period of 2014 2019 in showing up Sundanese woman is interesting to study, instead of showing up the political symbols in political communication space, either consciously or unconsciously represent Sundanese locality, because Women have achieved great success as party leaders and prime ministers, as candidates for high positions in national politics and as legislative candidates. 1 In political communication, the use of symbols either concrete and abstract symbol can not be avoided [12].

From the explanation of this research, then to formulated this research, the problem that is studied are : How the political communication of Chairman Of West Java Province Parliament for the period of 2014 - 2019 Ineu Purwadewi Sundari in showing up political identity of Sundanese woman as political symbols? With qualitative method and design of case studies.

\section{METHOD}

This research used qualitative approach with design of case studies, in his book Qualitative Inquiry and Research Design : Choosing Among Five Tradition, that case studies is an exploration from one bound system or one case/diverse case that from time to time through deep data collect and involve various information source that is rich in a context [13].

The observed case approach that is the political communication of Chairman of West Java Province Parliament for the period of 2014 - 2019 in showing up political identity of Sundanese woman. In this research, researcher tried to observe, understand, and analyze the process of the political communication of Sundanese woman, Ineu Purwadewi Sundari, Chairman of West Java Province Parliament for the period of 2014 - 2019 in showing up political identity of Sundanese woman. One character in qualitative research is to observe and interact with the subject of the research to try to understand their language and their interpretation towards their world.

In this research, researcher determine the informant with the use of purpossive sampling technique, where this technique includes people who have been selected based on certain criteria that the researcher requires based on the purpose of the research2. According to Cresswell the good informant criteria are : "all individuals studied represent people who have experienced the phenomenon", So, more precise to choose the informant that is really has capabilities because of his experience and able to articulate his experience and his point of view based on something questionable [14].

If we see the subject of the research is Ineu Purwadewi Sundari, Chairman of West Java Province Parliament for the period of 2014 - 2019, political actor (Sundanese 
woman politician), Party Secretary of the West Java DPD PDI Perjuangan, and Political Expert. As for the informants for this research in Table I, are :

TABLE I. LIST OF THE RESEARCH'S INFORMANT

\section{Research's Informant}

\begin{tabular}{|c|c|}
\hline Name & Information \\
\hline Dr. Abdy Yuhana, SH., MH & $\begin{array}{l}\text { Secretary of West Java } \\
\text { DPD PDI Perjuangan. }\end{array}$ \\
\hline Hj. Popong Otje Djundjunan & $\begin{array}{l}\text { Commission X member of } \\
\text { Parliament of the Republic } \\
\text { of Indonesia }\end{array}$ \\
\hline Muradi, Ph.D & Political Expert \\
\hline Ineu Purwadewi Sundari, S.Sos., MM & $\begin{array}{l}\text { Chairman of West Java } \\
\text { Province Parliament for the } \\
\text { period of } 2014-2019\end{array}$ \\
\hline
\end{tabular}

In determining informants that described above, of course its impossible without any certain reason and consideration, researcher chose informants who are competent and researcher considered that they have knowledge about the problem that is studied.

Data collection technique in this research sourced on primary data and secondary data. Primary data sourced on information that is given by the informants as the research's subject through in-depth interview. Like an interview with; Popong Otje Djunjunan, Commision X Member Parliament of the Republic of Indonesia (Sunday, June $11^{\text {st }} 2017$ - Cipaganti St., No. 128 Bandung City), and then interview with Dr. Abdy Yuhana, Sh.,MH, Secretary of West Java DPD PDI Perjuangan (Saturday, June $17^{\text {st }}$ 2017), interview with Ineu Purwadewi Sundari, S.Sos.,MM, Chairman of West Java Province Parliament (Tuesday, July $11^{\text {st }}$ 2017), and researcher did an interview with Muradi, P.hD, Political Expert (Friday, July 14 ${ }^{\text {th }}$ 2017).

Beside, also sourced on observe or series of observations that researcher did on the political communication of Chairman of West Java Province Parliament for the period of 2014 - 2019 in showing up political identity of Sundanese woman. Secondary data is data that is obtained from various sourced that related with things that are studied, in the form of books, magazines, newspapers, journals, dissertation, scrapbook, and other literatures that related with the research's problem.

According to researcher, the procedure of data collection directly through interview, observation as primary data in qualitative research as consequences that researcher must take to dig up data and informations on research's subject to get saturated point data besides secondary data that researcher collect through collecting documents and audio visual recording in the field, and researcher also chose that the collecting data done directly through interview process with informants, obseved their behavior, also supported by secondary data in the form of literature and supporting data source, where each other support and complement each other.

Moreover, the activity of data collection that researcher did refer to the activity of data collection by Creswell that is "A Data Collection Circle" (Creswell, 1998:109-135). The activity which is done with the Creswell model shows that each other is conected, started with place determination or individual. On the model "A Data Collection Circle" from Creswell, this approach process called as "Gaining Acces and Making Report" or approach process.

This Research used Data validity test in qualitative research covering several test. This data validity test is needed to determine whether a research is valid or not or the data that the researcher reported is what is actually happened in the field. The following is data validity checking techniques which was stated as follows [15].

1. Triangulation, a validity checking techniques that make use of something else.

2. Discussion with colleagues, to increase the accuracy of research results.

3. Member check, that is researcher collect the point of view from participants about the credibility from the findings and its interpretations [16].

While data analysis techniques that researcher use in this research is data qualitative analysis. According to explain that data analysis consists of :

1. Data Collection, that is existing data collection activities first. All of the important information which is related with this research's problem, and then grouped based on the topic of the problem.

2. Data Reduction, that is data reduction activities that have been obtained after collecting the data with sharpening analysis, classify, direct, and throw the data that is not needed and organized the data.

3. Data display is an activity of showing the data that have been obtained after reduced first.

4. Conclusing drawing \& verification is an activity of making conclusion by drawing or verify the data that have been obtained. This stage intended to avoid misinterpretation from interview with the informants that can obscure the real meaning of the problem from this research's focus [17].

The steps of data analysis that mentioned above is integral parts, so they are connected between one stage and another. The analysis carried out continuously from the beginning to the end of research, to know how the political communication of Chairman Of West Java Province Parliament for the period of 2014 - 2019 Ineu Purwadewi Sundari in showing up political identity of Sundanese woman as political symbols. 


\section{RESULTS And DISCUSSION}

This research shows that on perspective of socio cultural the communication tradition according to EM. Griffin in his book "A First Look at Communication Theory" elaborate seven tradition in the field of communication theory, socio-psychological, cybernetics, rhetoric, semiotics, socio-cultural, critical, and phenomenology [18].

The research that researcher did is at perspective of socio-cultural. In Griffin book lean on how language play a very important role that breeds culture in life or the reality in society. Basic assumption of this perspective is when people talk, that person is actually producing culture, as well as the research that researcher did, when a Sundanese Woman Politician talk with language (in communication, symbol is language), then culture production and reproduction will occur through symbols, through the language that is used in message delivery, so the reality is composed through interactions from indiviual or political actor.

Sundanese values is an identity that used in political communication space and then incarnate become political identity that attached on people is ethnophilosophical building in West Java. Although in fact either consciously or uncosciously West Java as a large house that accomodate Sundanes local entity that ethnophilosophical affects the patterns and the life of Sundanese people. Such things as logiccal consequences from conditions of diversity. The perspective of political communication that is loaded with the principle of ethical principles of civilization, morality, and responsibility in the frame of equality and respect for political people, then in order to build local politics, researcher interpretation, that how the political identity showing up the political symbols on West Java people become a strengthening when that political identity continue to be maintained according to the people of West Java's distinctive values civilization that in fact is Sundanese that silih asih, silih asah, and silih asuh, by maintaining a noble Sundanese.

Empirical study shows that political identity that is showed up by Ineu Purwadewi Sundari that is representated in political spaces, neither its Parliament, party, or constituents, researcher identified that the three political identity which then manifested into political symbols then attached to Ineu Purwadewi. First, the Sundanese identity. Second, the Islamic identity, Third, the party identity (the Ideology of Pancasila 1st June).

Such as interview with informants Abdy Yuhana, as the Secretary of West Java DPD PDI Perjuangan, said that, "Political identity is very important, because either consciously or uncosciously, want it or not, it means Sundanese identity, it will attached on her. Because it is blend and mixed with people daily life. It is impossible if Ineu never use Sundanese language." (Interview on June 17th 2017)
It's different with Ceu Popong, senior politician from West Java that is a member of Commission X Parliament of the Republic of Indonesia, that become researcher informants, also said that, "Political symbol is important. Considering that symbol as a parable form which with certain symbols, people will remember politician in certain ways, example : yeuh Ceu Popong mah da kieu jelemana, rapat oge kadang sok pake bahasa Sunda. (Ceu Popong is this typical person, in a meeting sometimes use Sundanese language)" (Interview, June 11th 2017).

As well as with informants Muradi, P.hD as political expert said that :

"What is your political background? Let say it like, political identity is initial base for someone to make himself a part of political community. If in a political system which is normal, its not odd, people will, let's say people from Jakarta, and then his mother and father based in PNI, then his mother is from Masyumi, but then his movement is identified as person then intergrated nationalist political understanding with modern political understanding. So, people will see as someone who has political base as someone that is imaged. For example, me, if I have close relationship with many places, I have many friends, and then, my big family is a friend of the old PNI, and then for example my parent, my father is NU Ansor, it can then become important to become my political identity. I might seem in front of a lot of people as a secular person,because I am more into carrying out non - religious political functions.But that's also, people will directly look for someone political base. Ohh..I understand, Oh.. it's reasonable.. And then, that is the base of political identity". (Interview, July 14th 2017)

Finding in the field First, Sundanese Culture Identity that is political symbol represented by Ineu Purwadewi Sundari through verbal communication. In political space, at Tatar Sunda, verbal communication are not less important than non-verbal language. Sundanese culture that is representated by Ineu Purwadewi Sundari is by using verbal communication that is Sundanese language. In political space, for example in the result of research that have been described, when she open a meeting or dialogue she said hello accompanied by Sampurasun. Sampurasun is West Java characteristic of saying hello. On perspective of the political communication, political language is a word game, language is not only capable to reflect reality, but even create a reality. The fact is, Ineu Purwadewi Sundari more dominant in using Indonesian language compared to Sundanese language when communicating.

Second, the Islamic identity that is representated by using clothes or clothing is a part of political symbol, by using hijab.There is an adage that mentioned that "politic is something from head to toe", it means in political appearance in dressing up also affect the political actor love or trust in front of the people. Clothes are not only described as body cover only, but more than that. In political clothing also can be used as political identity 
which makes a characteristic of that politician, even clothes can also shows a political attitude. For example, such as clothes that used by Soekarno, the uniform, and the cap. The cap in the era of national movement as a national struggle, so the uniform and the cap, became the political identity of Soekarno, or Jokowi with his plaid shirt. Without having to talk about it, people will know right away that is Jokowi. With that identity people easily remember the political actor. Therefore, in perspective of political communication, clothes can also give identity that breed certain image for the one who wear it, because clothes is a part of non-verbal communication.

Then, what about Ienu Purwadewi Sundari? Researcher found that Ineu Purwadewi Sundari that imaged as Sundanese woman did not use Sundanese clothes, for example : using sinjang (fabric) wrapped with kebaya and hair bun. Occasionally Ineu Purwadewi use Sundanese kebaya (Javanese blouse) that is only on certain event. Ineu Purwadewi, Chairman of West Java Province Parliament, tend to dressing up in formal or non-formal event neither in an event at Parliament, Party, or when meeting with constituent.

Such as, Political communication that includes political communication messages, also clothing, makeup, hairstyles, logo design, which are all elements of communication that are considered political images or identities.3.

Clothes as a non-verbal communication, even more in perspective of political communication, political identity that is highlighted by Ineu Purwadewi Sundari in terms of appearance nothing tends to be highlighted or become a characteristic that can be remembered by the people. So, the people are not familiar with the figure of Ineu Purwadewi Sundari as a Chairman of West Java Province Parliament. Ineu Purwadewi Sundari in the end does not have aything to be remembered. Meanwhile, as a representation of the reliigion that she adheres to, which is Islam, as a moslem woman, Ineu Purwadewi use hijab in every activity, neither at Parliament, Party, Constituent. The red color become a dominant color that she used. In the end, color become a political meaning, color as political identity from supporting political Party, that is PDI-Perjuangan.

Third, Party identity that is color is a symbol of political party. In political communication, color is a form of non - verbal communication. Color can also identified as a political attitude for the one who wear it. The color red and black is often used by Ineu Purwadewi Sundari. Ideology as an identity or a political party characteristic that is PDI Perjuangan. In non - verbal message, Ineu Purwadewi often use clothing with red or balck color on several occasions on the political stage as an identity of the political party. However, the red color is become the dominant color that is used by Ineu Purwadewi Sundari. Beside color, ideology is also a basis of struggle or future goals that is want to be achieved by a political party. As a follower of Pancasila June 1st, a value, beliefs, and norms, have to be reflected in the way of thinking, behave, and act. Logical implications of how Ineu Purwadewi Sundari makes a policy based on the ideology that she adopted that is Pancasila June 1st. So far, her participations as a chairman of Parliament in practicing the values of Pancasila June 1st, for example, she made a regional regulations in accordancewith the local wisdom that is in West Java.

Ineu Purwadewi Sundari once again cannot avoid that local wisdom is very important to maintain the identity of a civilization. For a group of civilizations that is hold firm to its custom, will assume that local wisdom have a good value and correct, and hereditary. Local wisdom as an advice, beliefs, or abstinence for the adherents of the habits, so they can conserve their custom and also their resource.

Either onsciously or unconsciously, the building of political identity of Sundanese become important that is can affect a political actor, neither it political elite or grassroots. Ineu Purwadewi, as a representation of West Java People especially Sundanese people, have a strategic positions as a top leader of West Java Province Parliament, at least every policy have to be sourced on local wisdom that is in West Java, implemented in Parliament, Party, or constituent space.

The practice, must be recognized honestly that there is exploitation on political identity. Can be said that "pseudo of political identity" that is pretense or fake when $\mathrm{Ki}$ Sunda as a local genius are not implemented as the subject of her actions, as a personal that fully grounded on West Java values or Sundanese values, which is stated in idea, notion, also policy based on feelings, loves her own Indonesia. Also how is the Sundanese values in political space no longer used as a foundation of life, politcal identity which should maintained and implemented are only exploited for pragmatic purposes. When Ineu Purwadewi Sundari, Chairman of Parliament West Java Province that is imaged as a Sundanese woman, at least Ineu Puwadewi Sundari must be able to reflect herself and what is her characteristic as Sundanese, if Sundanese itself is her identity. Keep in mind, the importance of political image is an initial foundation for Ineu Purwadewi Sundari future careers.

Researcher found a model of how the political communication Chairman of West Java Province Parliament for the period of $2014-2019$ n showing up political identity of Sundanese woman as a political symbols in Figure 1, as follows : 


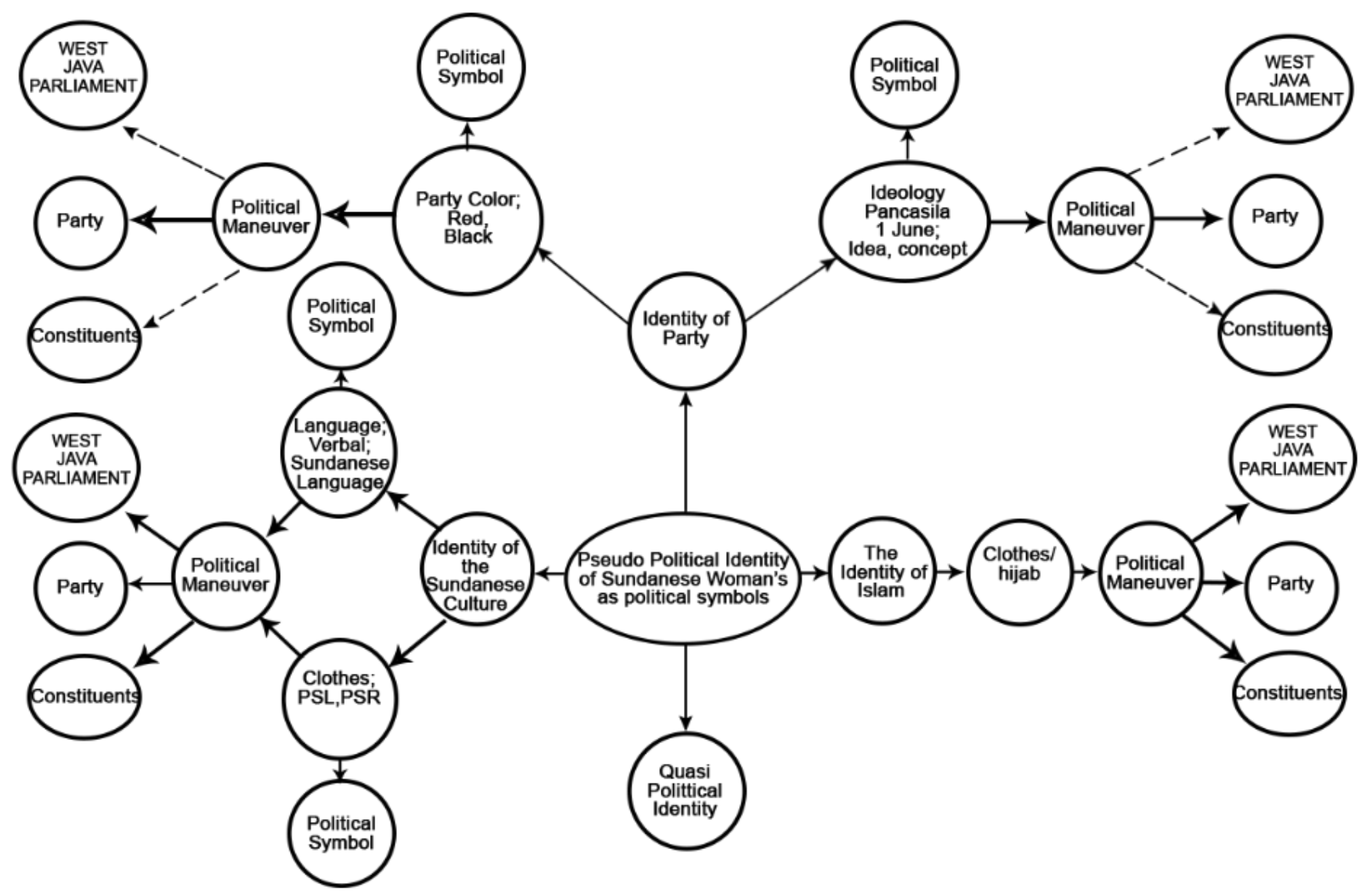

Fig 1. The political communication Chairman of West Java Province Parliament for the period of 2014 - 2019 Ineu Purwadewi Sundari in showing up political identity of Sundanese woman as political symbols Source : Researcher, 2017

\section{CONCLUSION}

Based on the result of the research that have been described about the political communication Chairman of West Java Province Parliament for the period of 2014 2019 2019in showing up political identity of Sundanese woman, can be concluded that; Political identity that is used by a Sundanese woman Ineu Purwadewi Sundari, Chairman of West Java Province Parliament for the period of 2014 - 2019 in showing up political identity of Sundanese woman. The political identity that attached on Ineu Purwadewi Sundari that is representated in political spaces neither Parliament, Party, or Constituent, there are three political identity that attached on Ineu Purwadewi. First, Sundanese identity. Second, Islamic identity.
Third, Party identity. Either it consciously or unconsciously, the building of political identity of Sundanese become important that is can affect a political actor, neither it political elite or grassroots.The practice, must be recognized honestly that there is exploitation on political identity.

Can be said that "pseudo of political identity" that is pretense or fake when Ki Sunda as a local genius are not implemented as the subject of her actions, as a personal that fully grounded on West Java values or Sundanese values, which is stated in idea, notion, also policy based on feelings, loves her own Indonesia. Also how the Sundanese-values in political space are no longer used as as a foundation of life, politcal identity which should maintained and implemented in political space. 


\section{REFERENCE}

[1]Arifin, Anwar. Komunikasi Politik (Paradigma, Teori, Aplikasi, Strategi Komunikasi Politik Indonesia). Jakarta : PT. Balai Pustaka. 2011, pp.13

[2] Arifin, Anwar. Komunikasi Politik (Paradigma, Teori, Aplikasi, Strategi Komunikasi Politik Indonesia). Jakarta : PT. Balai Pustaka. 2011, pp.16

[3] Bagir, Zainal Abidin, Pluralisme Kewargaan, Arah Baru Politik Keragaman di Indonesia, Mizan dan CRCS. BandungYogyakarta. 2011, pp.20

[4] Nimmo, Dan. Komunikasi Politik Komunikator, Pesan dan Media. Bandung : PT : Remaja Rosdakarya. 2006. Pp. 79

[5] Suryadi. Karim. Kedudukan Platform dan Komunikasi Politik Kiai dalam Membentuk Identitas Kepartaian (Studi Kasus pada Partai Kebangkitan Bangsa dalam Pemilihan Umum 1999 dan 2004). Bandung

: Desertasi Program Pascasarjana Bidang Kajian Utama Ilmu Komunikasi, Universitas Padjadjaran.(Unpad). 2006

[6] Zakiyuddin, Ahmad. Komunikasi Politik Jalaluddin Rakhmat Studi Kasus Pemilu 2014 di Kabupaten Bandung dan Kabupaten Bandung Barat. Desertasi. Program Ilmu Komunikasi Pasca Sarjana Universitas Padjajaran (Unpad). 2017.

[7] Hikmat, Mahi M. Komunikasi Politik Calon Kepala Daerah Pada Pemilihan Langsung (Studi Kasus pada Pemilihan Gubernur dan Wakil Gubernur Jawa Barat Tahun 2008). Bandung : Desertasi Program Pascasarjana Ilmu Komunikasi Universitas Padjajaran (Unpad). 2010.

[8] Winahyu Dwi Utami. Komunikasi Politik Anggota Legislatif Provinsi Riau. (Studi Fenomenologi Tentang Keterwakilan Perempuan di DPRD Riau). Bandung. Tesis. Program Pasca Sarjana Ilmu Komunikasi Universitas Padjajaran (Unpad). 2010.

[9] Permatasari. Hambatan - Hambatan Partisipasi Politisi Perempuan (Studi Kasus di Provinsi Daerah Yogyakarta). Yogyakarta. Tesis. Ilmu politik Program Pascasarjana Universitas Gadjah Mada (UGM). 2013.

[10] Anigwe, Annette. Desertasi. Perception of Women in Political Leadership in Nigeria. Walden University. US. 2014.

[11]Susanto, Harry Eko. 2017 Jokowi's Political Communication in Jakarta governor Election to Win Age-Based Voters dari Tarumanegara University yang diterbitkan di Mediterranean Journal of Social Sciences. [12]Creswell J.W. Penelitian Kualitatif \& Desain Riset: Memilih diantara lima pendekatan. Yogyakarta : Pustaka Pelajar. 2014. Pp. 350

[13]Kriyantono, R. Teknik Praktis Riset Komunikasi: Disertai Contoh Praktis Riset Media, Public Realation, Advertising, Komunikasi Organisasi, Komunikasi Pemasaran. Jakarta: Kencana. (2007). Pp. 154

[14]Creswell J.W. "Qualitative Inquiry and Research Design: Choosing Among Five Traditions" by J. W. Creswell, Pp. 118, 1998.

[15]Moleong, Lexy J. Metodelogi Penelitian Kualitatif, Bandung, PT. Remaja Rosda Karya.2002. pp. 327-339

[16]Creswell J.W. Penelitian Kualitatif \& Desain Riset: Memilih diantara lima pendekatan. Yogyakarta : Pustaka Pelajar, Pp. 350, 2014

[17]Miles, M.B.and A.M. Huberman Qualitative Data Analysis: A Sourcebook of New Methods, Sage Publications, USA, 1984.

[18]Griffin ,EM. A First Look At Communication Theory. 5th ed. New York: Mc Graw Hill. Pp. 21 